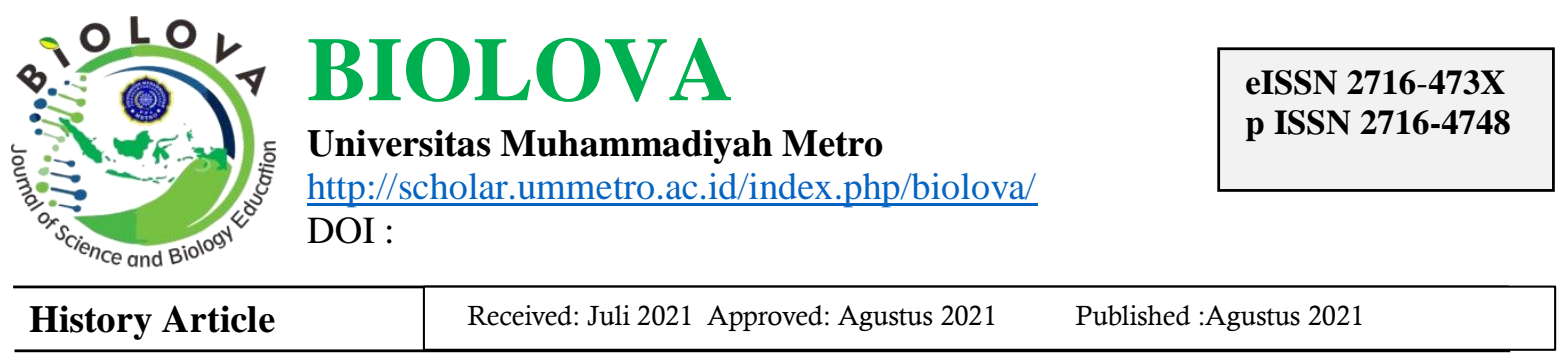

\title{
ANALISIS PENTINGNYA PENGEMBANGAN MODUL BIOLOGI BERBASIS POTENSI LOKAL DENGAN MENGINTEGRASIKAN NILAI-NILAI KEISLAMAN
}

\author{
Yuni Susilawati ${ }^{1}$ Muhfahroyin $^{2}$ \\ ${ }^{1,2}$ Universitas Muhammadiyah Metro \\ 1Email: yunisusilawatii0592@gmail.com ${ }^{2}$ muhfahroyin@yahoo.com
}

\begin{abstract}
Abstrak: Pendidikan memiliki peran yang sangat penting dalam rangka pembangunan bangsa dan negara. Pendidikan merupakan bagian dari pembinaan mental yang diarahkan pada upaya mencerdaskan kehidupan bangsa dan pembangunan segenap pribadi untuk mengisi kemerdekaan bangsa dan Negara Kesatuan Republik Indonesia. Potensi lokal sekolah merupakan wahana pembelajaran biologi yang dapat diangkat sebagai sumber belajar dan hasil penggalian dapat disusundalam bentuk bahan ajar yang dikemas dalam bentuk media pembelajaran berupa modul biologi. Penyusunan kegiatan pembelajaran didasarkan pada potensi sekolah berupa potensi lingkungan sekolah. Objek permasalahan biologis yang ada pada potensi lokal sekolah antara lain: (1) Struktur fungsi tumbuhan di sekitar halaman sekolah, baik morfologi maupun anatomi; (2) Fisiologi tumbuhan, misalnya proses fotosintesis jika dikaitkan dengan intensitas cahaya dan kandungan klorofil daun; (3) Penyakit tanaman dan penyakit di sekitar halaman sekolah; (4) Ekosistem. Untuk memanfaatkan peluang besar tersebut, penelitian ini bertujuan untuk menganalisis pentingnya pengembangan modul pembelajaran. Pembuatan modul pembelajaran ini menggunakan model 4D yang merupakan model pengembangan yang terdiri dari 4 tahap.
\end{abstract}

Kata kunci: modul biologi, potensi lokal, nilai-nilai keislaman

Abstract: Education has a very important role in the framework of building the nation and state. Education is part of mental development that is directed at efforts to educate the life of the nation and the development of the whole person to fill the independence of the nation and the Republic of Indonesia. The local potential of the school is a vehicle for learning biology, which can be appointedas a source of learning and the results of the excavation can be organized in the form of teaching materials, which are packaged in the form of instructional media in the form of biology modules. The preparation of learning activities is based on the potential of the school in the form of the potential of the school environment. The objects of biological problems that exist in the local potential of schools include: (1) The structure of plant functions around the school grounds, both morphology and anatomy; (2) Plant physiology, for example the process of photosynthesis if associated with light intensity and leaf chlorophyll content; (3) Plant diseases and diseases around the school grounds; (4) Ecosystems. To take advantage of this great opportunity, this study aims to analyze the importance of developing learning modules. The making of this learning module uses the 4D model which is a development model consisting of 4 stages.

Keyword: biology module, local potential, Islamic value

\section{How to Cite}

Susilawati, Yuni, Muhfahroyin. 2021. Analisis Pentingnya Pengembangan Modul Biologi Berbasis Potensi Lokal dengan Mengintergrasikan Nilai-Nilai Keislaman. Biolova 2(2). 103-107. 
Pendidikan mempunyai peranan yang sangat penting dalam rangka membangun Bangsa dan Negara. Pendidikan merupakan bagian dari pembangunan mental yang diarahkan kepada usaha mencerdaskan kehidupan bangsa serta pembangunan manusia seutuhnya untuk mengisi kemerdekaan bangsa dan Negara Republik Indonesia. Pendidikan merupakan aktivitas terencana dan terprogram untuk terwujudnya pendidikan nasional yang tercantum dalam Peraturan Pemerintah Nomor 32 tahun 2013 tentang Standar Nasional Pendidikan. Dalam Peraturan Pemerintah tersebut dijelaskan bahwa kompetensi adalah seperangkap sikap, pengetahuan dan keterampilan yang harus dimiliki, dihayati dan dikuasai oleh peserta didik setelah mempelajari suatu muatan pembelajaran.

Peran pendidik tidak terlepas dari bahan ajar. Proses pembelajaran akan berjalan secara efektif dan efesien jika tersedia media pembelajaran yang berkualitas. Modul merupakan salah satu bentuk inovasi media pembelajaran yang dapat digunakan dalam proses pembelajaran. Modul dapat diartikan sebagai salah satu media pembelajaran yang disusun dengan tampilan yang menarik dengan penggunaan bahasa yang mudah dipahami untuk membantu peserta didik mencapai suatu tujuan pembelajaran. Hal ini menunjukan begitu pentingnya media dalam proses pembelajaran.

Hasil wawancara guru dan beberapa peserta didik pada tanggal 7 Oktober 2019 di SMA N 1 Bukit Kemuning diperoleh data sebagai berikut; 1) Media dalam proses pembelajaran masih klasik, 2) Guru belum memiliki media pembelajaran yang di dalamnya terdapat nilai-nilai keislaman khususnya mata pelajaran biologi, 3) Proses pembelajaran guru masih jarang menghubungkan materi dengan nilai-nilai keislaman. 4) Proses pembelajaran di SMA N 1 Bukit Kemuning masih menggunakan buku paket dan LKS, 5) Belum pernah dikembangkan media pembelajaran berupa modul berbasis potensi lokal oleh guru atau peneliti lainnya yang digunakan di kelas $\mathrm{X}$. Tentunya keadaan tersebut sangat disayangkan karena potensi lokal sekolah bisa memberikan dukungan terhadap aktivitas belajar peserta didik. Potensi lokal sekolah dapat dikemas dalam Lembar Kegiatan Siswa (LKS) maupun Pelaksanaan Pembelajaran (RPP).

Berdasarkan

permasalahan terbatasnya bahan ajar yang aktual dan belum dikembangkan potensi lokal di atas peneliti tertarik mengembangkan modul potensi lokal dengan mengintegrasikan nilai-nilai keislaman sebagai media pembelajaran biologi pada materi Ekosistem. Modul pembelajaran dikembangkan oleh peneliti sebagai media pembelajaran yang dikemas agar menarik, dan diharapkan modul pembelajaran dapat meningkatkan belajar peserta didik, serta menguraikan materi baik diawal sub bab maupun diakhir dengan mengintegrasikan nilai-nilai keislaman yang bersumber pada Al-Qur'an dan Hadist.

Muhfahroyin (2007) menyatakan bahwa pembelajaran konstektual dalam pembelajaran biologi dapat membentuk karakter iman dan kesadaran tuhan peserta didik (takwa) dan pada saat yang sama melatih keterampilan proses sains. Maka dari itu harapannya dapat menciptakan peserta didik yang berprestasi, unggul dan berakhlakul karimah.

Berdasarkan rumusan masalah maka tujuan penelitian pengembangan yaitu menghasilkan modul pembelajaran berbasis potensi lokal dengan nilai-nilai keislaman yang bersumber pada Al-Qur'an dan Hadist sebagai pembelajaran biologi materi ekosistem, menyelesaikan masalah serta memenuhi kebutuhan dengan menggunakan modul pembelajaran berbasis potensi lokal yang benar dan bisa digunakan sebagai prasarana dan sarana pembelajaran. Peserta 
didik akan termotivasi dan tidak jenuh jika pembelajaran dilakukan tidak hanya diruang kelas, tetapi juga dilingkungan sekitar sekolah.

Muhfahroyin (2017) menyatakan bahwa bahan ajar yang dikembangkan secara konstektual sangat membantu peserta didik untuk memfasilitasi mereka mempelajari konsep dan prinsip sains yang lebih tinggi. Pemahaman sains yang memadai akan membantu peseta didik untuk mengatasi masalah yang berkaitan dengan sains dalam kehidupan sehari- hari. Bahan ajar dapat digunakan dan dikembangkan oleh guru dalam pemanfaatan sumber belajar. Sumber belajar yang bisa digunakan guru yaitu menggunakan modul pembelajaran berbasis potensi lokal.

Modul adalah pelajaran yang disusun dan disajikan berupa materi secara tertulis sehingga pembacanya dapat menyerap materi sendiri, materi pelajaran pada suatu modul, kerangka isi modul, disusun dan disajikan sedemikian rupa supaya peserta didik bisa memahami sendiri materi yang disajikan. Kita ketahui tidak jarang buku-buku yang digunakan sekarang lebih banyak berupa buku cetak yang terkadang bosan untuk membacanya, sehingga tidak memberi pengaruh minat baca peserta didik dan hasil belajar menjadi rendah, Rumitnya bahan ajar yang digunakan membuat peserta didik tidak tertarik membaca buku biologi. Peserta didik lebih tertarik membaca buku yang bergambar terang dibandingkan buku pelajaran, sedangkan modul pembelajaran memiliki alur isi yang runtun berurutan serta gambar yang cerah, menarik, dan mudah di ingat sehingga akan membuat peserta didik semangat untuk belajar

Modul adalah bahan ajar cetak (printed,) (Ahmadi dkk., 2011) menyatakan bahwa modul merupakan satuan program pembelajaran terkevil. Pembelajaran menggunakan modul merupakan strategi tertentu dalam menyelenggarakan pembelajaran individual.

Muspiroh (2013:489) "menyatakan

bahwa integrasi nilai-nilai islam dalam pembelajaran sains akan memberikan kekuatan ranah kognitif, afektif dan psikomotorik".

Pelaksanaan pembelajaran di sekolah akan menghasilkan mencakup keseluruhan ranah belajar. Dengan ini dapat memberikan pandangan yang tidak sama karena selama ini yang banyak terjadi hanya ranah kognitif yang sering dikembangkan dalam pembelajaran di sekolah.

\section{METODE}

Penelitian ini merupakan penelitian pengembangan, adapun yang dikembangkan berupa modul pembelajaran. Prosedur yang dilakukan dalam penelitian pengembangkan modul ini yaitu model pengembangan seperti yang disarankan oleh Thiagarajan dan Semmel (Trianto, 2011:189) adalah Model 4-D. Langkah model pengembangan ini ada 4 tahaan, yaitu Define, Design, Develop, dan Desseminate. Define (Pendefinisian) merupakan prosedur yang digunakan dalam mengembangkan modul ini.

Langkah-langkahnya yaitu prasurveidengan melakukan observasi dan wawancara, dengan melihat masalah serta menganalisis kebutuhan media SMA N 1 Bukit Kemuning. Wawancara dilakukan oleh peneliti terhadap guru dan beberapa peserta didik kelas $\mathrm{X}$ IPA SMA N 1 Bukit Kemuning.

\section{HASIL}

Berdasarkan hasil wawancara di atas maka dilakukannya analisis pentingnya pengembangan modul berbasis potensi lokal ini mengenai media yang digunakan dalam proses pembelajaran khususnya mata pelajaran biologi, yaitu: 1) Perlunya modul penunjang terhadap proses pembelajaran, 2) Perlunya pengembangan modul berbasis 
potensi lokal sesuai dengan teknologi modern dan perkembangan ilmu, 3) Pengembangan modul berbasis potensi lokal ini sudah berkemajuan, di mana dalam penggunaanya nanti lebih memudahkan peserta didik dalam belajar 4) Modul berbasis potensi lokal ini nantinya akan berintegrasi nilai-nilai keislaman yang bersumber pada Al- Qur'an dan Hadist 5) Modul berbasis potensi lokal diharapkan dapat memenuhi kebutuhan sekolah dalam proses pembelajaran sebagai media penunjang yang memiliki teknologi berkemajuan serta terintegrasinnya nilai-nilai spiritual. Berdasarkan hasil analisis di atas maka perlu dikembangkan modul berbasis potensi lokal biologi dengan mengintegrasikan nilai-nilai keislaman.

\section{PEMBAHASAN}

Modul biologi berbasispotensi lokal ini telah dirancang agar kebutuhan proses pembelajaran peserta didik dalam mengeksplor dan memahami materi yang diberikan oleh guru terpenuhi. Modul biologi berbasis potensi lokal yang dikembangjan didesain tidak hanya menyajikan teori dan latihan saja atau segi kognitifnya saja melainkan peserta didik dapat dengan mudah memahami isi modul dan membantu peserta didik dalam belajar. Wijaya (dalam Daryanto, 2014:178) menyatakan modul adalah satu unit program belajar mengajar terkecil secara detail dengam tujuan istruksional khusus, tujuan instruksional umum, topik yang dijadikan pangkal proses belajar mengajar, pokok-pokok materi yang diajarkan dan dipelajari, fungsi dan kedudukan modul dalam kesatuan program yang lebih luas, sumber belajar dan alat yang akan digunakan, peranan guru saat proses pembelajaran, lembar kerja yang digunakan selama berjalannya proses belajar, dan keikatan pembelajaran yang harus dihayati dan dilakukan peserta didik secara urutan.

Kelebihan dari modul yaitu: a) Menggunakan gambar yang menjelaskan materi dari modul. b) Menggunakan warna yang terang dan menarik sehingga peserta didik termotivasi membaca modul pembelajaran Vembriarto (1981:25), menyatakan bahwa kelebihan modul ini yaitu: a) Dapat mengatasi ruang dan waktu yang terbatas baik guru maupun peserta didik. b) Dapat digunakan dengan bervariasi namun tepat seperti dapat menumbuhkan semangat atau motivasi dalam belajar, mengembangkan kemampuan berinteraksi langsung dengan lingkungan belajar. c) Peserta didik bisa mengevaluasi sendiri hasil belajarnya. d) Peserta didik menjadi lebih aktif belajar. e) Guru tidak semata-mata sebagai pengajar namun berperan sebagai pembimbing. f) Peserta didik menjadi terbiasa percaya pada diri sendiri. g)Peserta didik menjadi sehat dalam berkompetensi. h) Efektif dalam belajar, i) Dapat menarik perhatian anak sehingga pelajaran menunjukkan lebih berhasil dan mudah dipahami dibandingkan dengan ceramah.

\section{KESIMPULAN}

Pengembangan modul berbasis potensi lokal dengan nilai-nilai keislaman perlu dikembangkan sebagai modul penunjang proses pembelajaran biologi.

\section{SARAN}

Saran dari penelitian pengembangan ini yaitu: 1) Penelitian pengembangan modul sebaiknya diberi jadwal target untuk menyelesaikan modul secara terperinci agar tidak timbul kesalahan akibat pembuatan modul yang terburu-buru. 2) Peneleitian pengembangan selanjutnya, sebaiknya dalam pembuatan modul dikerjakan langsung oleh peneliti sehingga hasil yang diperoleh sesuai dengan keinginan peneliti. 3) Modul yang telah dihasilkan dapat diuji coba kembali ke beberapa sekolah dengan kelompok yang lebih besar agar menghasilkan produk yang lebih representatif. 
DAFTAR RUJUKAN

Ahmadi, I. K., Amri, S., Elisah, T. 2011. Strategi Pembelajaran sekolah Terpadu. Jakarta: Prestasi Pustaka.

Daryato, D. 2014. Pengembangan Perangkat Pembelajaran. Yogyakarta: Gava Media.

Muhfahroyin. Anak A. O. 2017. Profiles of Contektual Teaching Material for Forest Prototype BasedCollaborative Learning. Biologi Education Of Muhammadiyah University of Metro. 8 ICLS 2017.
Muhfahroyin. 2007. Pendekatan Contextual Teaching and Learning untuk Mengintegrasikan IMTAQ dalam Pembelajaran Biologi. Jurnal Pendidikan dan Pembelajaran. Volume 5 Nomor 1

Muspiroh. N. 2013. Integrasi Nilai Islam dalam Pembelajaran Ipa. Jurnal Nilai Islam. Vol. XXVII. No. 3. Institut Agama Islam Negeri Syekh Hurjati: Cirebon.Trianto. 2010. Modul Pembelajaran Terpadu. Jakarta: Bumi Aksara. 